\title{
Conceptual shifts in animal systematics as reflected in the taxonomic history of a common aquatic snail species (Lymnaea stagnalis)
}

\author{
Maxim V. Vinarski ${ }^{1,2}$ \\ 1 Museum of Siberian Aquatic Molluscs, Omsk State Pedagogical University. 14 Tukhachevskogo embankment, Omsk, Russia. 644099 \\ 2 F.M. Dostoyevsky Omsk State University. 28 Andrianova Str., Omsk, Russia, 644077 \\ http://zoobank.org/EB27EC94-7D9F-482A-BEC0-334E89C24C11 \\ Corresponding author: Maxim V.Vinarski (radix.vinarski@gmail.com)
}

\begin{abstract}
Received 14 January 2015

Accepted 17 May 2015

Published 8 July 2015

Academic editor:

Matthias Glaubrecht

\section{Key Words}

Animal taxonomy

historical development

species

Historia naturalis

malacology

Lymnaea stagnalis (L., 1758) is among the most widespread and well-studied species of freshwater Mollusca of the northern hemisphere. It is also notoriously known for its huge conchological variability. The history of scientific exploration of this species may be traced back to the end of the $16^{\text {th }}$ century (Ulisse Aldrovandi in Renaissance Italy) and, thus, L. stagnalis has been chosen as a proper model taxon to demonstrate how changes in theoretical foundations and methodology of animal taxonomy have been reflected in the practice of classification of a particular taxon, especially on the intraspecific level. In this paper, I depict the long story of recognition of L. stagnalis by naturalists and biologists since the $16^{\text {th }}$ century up to the present day. It is shown that different taxonomic philosophies (essentialism, population thinking, tree thinking) led to different views on the species' internal structure and its systematic position itself. The problem of how to deal with intraspecific variability in the taxonomic arrangement of $L$. stagnalis has been a central problem that made systematists change their opinion following conceptual shifts in taxonomic theory.
\end{abstract}

great pond snail

Lymnaea stagnalis

\section{Introduction}

The development of science as a whole, as well as the progress of a particular scientific discipline, is a complicated and diverse process with many separate aspects (Hull 1988) that permit several distinct ways to represent the history of science. In my opinion, at least three approaches are imaginable in this case. Firstly, any history is a story telling us about a temporal sequence of events. It means that a narrative approach, which is merely an account of persons and their discoveries, is inevitable. Secondly, one may focus on conceptual shifts in scientists' minds that reflect the theoretical rather than temporal development of science. This approach presupposes a study of continuous changes in scientific concepts and ideas as well as in the methodological foundations of the art of doing science. It may well be a non-linear process since the development of theories does not always run parallel with the progressive sequence of events. Lastly, any description of the practical aftermath of these conceptual shifts may be considered as the third approach to the history of science. It encompasses the "external" manifestations of scientific activity, including modes of representing of knowledge, scientists' social interactions, university curricula, working classifications of studied objects, and so on.

Biological systematics is, probably, the oldest of the branches of life sciences. Its roots may be traced back to the pre-scientific epoch, since so-called "ethnotaxonomy" was just the first attempt to capture biological diversity by using more or less implicit categories and vernacular names (Atran 1990). The picture of the development of biological systematics is usually drawn following either a strictly narrative or conceptual (a history of ideas) approach (Stevens 1994; Wilkins 2009; Pavlinov and Lyubarskiy 2011), but this process has other inter- 
esting sides. It includes also the histories of the scientific exploration of particular taxa and their appreciation by practicing systematists. Some of these taxa are so spectacular and valuable practically that the history of their taxonomic treatment is as long as the history of systematics itself. Other species are less important, especially for folktaxonomists, and their taxonomic study started later in the epoch of the early systematics of the sixteenth and seventeenth centuries. To reconstruct the taxonomic history of an individual taxon is an important challenge allowing one to understand deeply the historical development of biological classifications and their practical issues (Schmidtler 2011).

The aim of this paper is to outline the taxonomic history of a widespread and commonly known invertebrate species in Europe and North America - the great pond snail, Lymnaea stagnalis (Linnaeus, 1758). The material for the study was obtained during my work with malacological collections of the Zoological Institute, Russian Academy of Sciences (Sankt-Petersburg; ZIN hereafter), Göteborgs Naturhistoriska Muséet (GNM hereafter), Vienna Museum of Natural History, Austria (NHMW hereafter), Naturhistoriska riksmuseet, Stockholm (Sweden), and Zoological Museum of the Copenhagen University, Denmark (ZMUC hereafter). These collections contain a large number of samples of $L$. stagnalis collected and identified by prominent malacologists of the end of the $18^{\text {th }}-$ the first half of the $20^{\text {th }}$ centuries, and examination of these materials helped me to understand how the taxonomists' views changed with time and to trace these changes by analysis of the information available from museum labels. The extensive search through old taxonomic literature has been carried out as well. I used the books kept in ZIN and NHMW libraries and utilized those fantastic facilities provided by electronic archives such as Biodiversity Heritage Library (http://www.biodiversitylibrary.org/).

It is a freshwater pulmonate snail (Fig. 1) using atmospheric air for breathing that allows it to migrate over long distances and to gain a foothold in waterbodies of

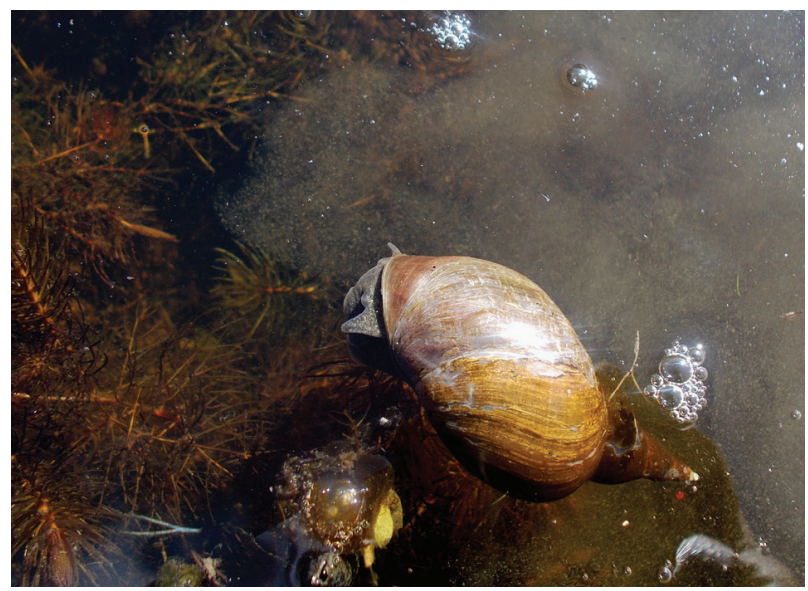

Figure 1. A great pond snail in its natural environment. 12.08.2014. Russia, Western Siberia, “Malaya Sos'va” Nature Reserve, Kopanoye Lake (photo: M. Vinarski). different types. L. stagnalis is characterized also by extreme ecological plasticity and enormous variation in its shell size and proportions (Kobelt 1871; Hubendick 1951; Arthur 1982; Vinarski 2014a). Being, very likely, the largest species of freshwater snails in Europe, the great pond snail had attracted the attention of naturalists long before Linnaeus. The first scientific description of this species appeared nearly 400 years ago (see below). The taxonomic history of $L$. stagnalis will serve here as a mirror to reflect shifts in taxonomical practice driven by conceptual changes in animal taxonomy which occurred between the $16^{\text {th }}$ and $21^{\text {st }}$ centuries.

\section{Lymnaea stagnalis in pre-Linnaean zoology}

Though the accepted scientific name of this snail should be credited to Linnaeus (1758), it had been repeatedly described under different names by predecessors of the great Swede. It seems a bit strange that such a large and abundant snail was utterly overlooked by the Ancient naturalists. Though, as Eduard von Martens (1860) noted in due time, the Greeks and Romans had very little interest in continental mollusks, both aquatic and terrestrial. The Ancient naturalists generally neglected them, and neither Aristotle nor Pliny the Elder nor any of the secondary Ancient authors described continental mollusks in detail. Aristotle, in his influential Historia animalium (HA) mentions only a certain kind of "lake oysters" (limnostrea, see HA IV, 40, 67) as well as some obscure "land ostracoderms" not divided into species (? helicid snails; see HA IV, 38).

The only (and rather curious) alleged mention of the pond snail in Antiquity belongs not to a naturalist but to an anonymous poet who was the author of the mock poem Batrachomyomachia ("Battle of Frogs and Mice") intended to mimic the Homer's masterpiece The Iliad. The poet describes the armour of the Frogs preparing to battle with the Mice:

"...their bucklers were Good thick-leaved cabbage, proof ' gainst any spear; Their spears sharp bulrushes, of which were all Fitted with long ones; their parts capital They hid in subtle cockleshells from blows" (Chapman 1888: 10).

The German malacologist Menke (quoted after Jeffreys 1862) tried to determine the identity of these subtle cockleshells mentioned by Pseudo-Homer. He supposed it may have belonged to Lymnaea stagnalis. This hypothesis was criticized by Jeffreys (1862), who said that it is quite impossible to judge conclusively on this subject. The Greek text is so concise that it gives no chance to choose among large species of aquatic snails inhabiting Greece and to decide which of them provided the Frogs with their helmets. As Jeffreys (1862: 113) stated, "it 

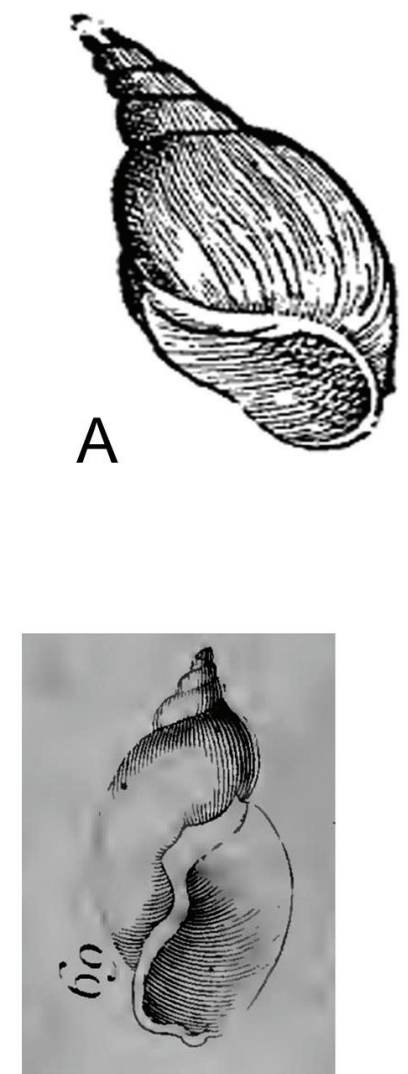

D
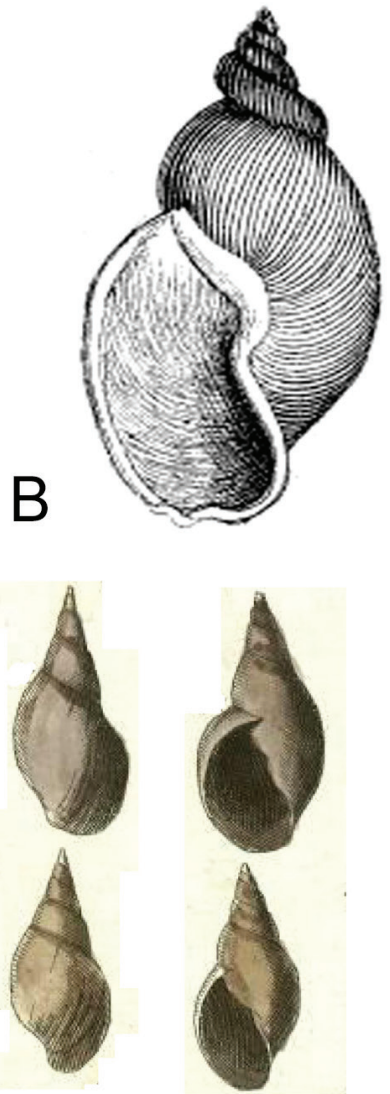

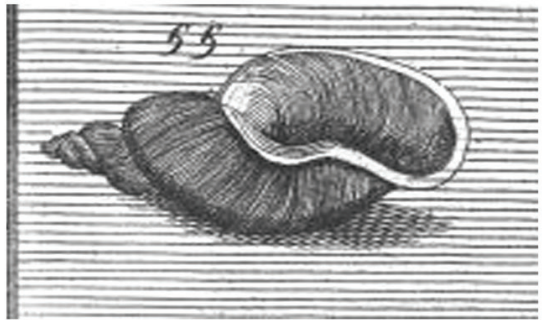

C
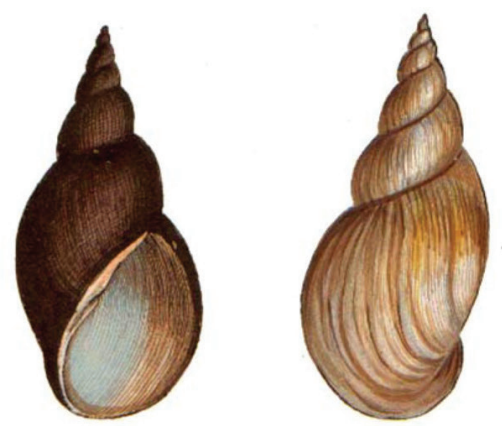

$\mathrm{F}$

Figure 2. Evolution of accuracy in illustrations of L. stagnalis shell through two centuries. Sources of images: A. Aldrovandi 1606. B. Lister 1678. C. Bonanni 1681. D. Klein 1753. E. Seba 1758. F. Schröter 1779.

is not likely that Homer was a conchologist, or distinguished one shell from another for poetical purposes. The kind of shells in question must have made cumbersome helmets for the valiant Frogs".

Medieval descriptive zoology, being deeply dependant on the works of Aristotle and other Ancient naturalists, overlooked L. stagnalis as well. One need only envisage the image of this snail in the very crude drawings of aquatic snails which appeared at the end of the fifteenth century (see Allmon 2007, fig. 2). It is impossible, though, to judge on their true taxonomic identity with any certainty.

The first naturalists of early Modern Europe interested in aquatic animals, namely Pierre Belon (1517-1564), Guillaume Rondelet (1507-1566), and Konrad Gessner (1526-1565), did not mention the great pond snail either. Though these authors were not slavish commentators of the Greek and Roman texts and added their own observations on aquatic creatures, they were more interested in marine mollusks than in freshwater ones.

The first record of the great pond snail in the European scientific literature I managed to find is that by Ulisse Aldrovandi (1522-1605), a junior contemporary of Belon and Gessner. His posthumous treatise De reliquis animalibus (Aldrovandi 1606) contains a mention of this species that opens a long list of L. stagnalis recordings in early animal systematics. Aldrovandi's book also contained the first "scientific" illustration of the L. stagnalis shell (Fig. 2A) that allows us to ascertain its taxonomic identity definitely. It does not matter that the shell in this picture is sinistral (pond snails have normally dextral, or right-coiled, shells). Though sinistral mutant individuals are sometimes found in L. stagnalis populations (Vinarski 2007), I believe that Aldrovandi or his engraver had a normal (i.e. dextral) shell of this snail in their hands. The usual technique of engraving in the sixteenth and seventeenth centuries demanded that the plate must be a mirror image of the object to be illustrated. The printers usually were "not preparing a reversed engraving (on wood or copper), but carving the image [of a shell] as it appeared, which would produce a reversed image when printed" (Allmon 2007: 175). The biological mechanism of inversions in shell coiling in snails was not known and thus remained irrelevant for authors which permitted them to present their shells in "wrong" mirror appearance. The picture of L. stagnalis shells with right coiling direction did not appear in a printed book until 1681 (see Fig. 2C).

Aldrovandi (1606) gave no formal description of the great pond snail. More precisely, the Latin name of the snail ("Turbo laevis item in stagnis degens"; Aldrovandi 1606: 358) served as its proper description at this time. The early taxonomists were far from using binomial nomenclature consistently, and the species' names produced by them were polynomials. Each polynomial should contain several words whose quantity corresponded to the number of es- 
Table 1. Polynomial taxonomic names proposed for the great pond snail in the $17^{\text {th }}$ and $18^{\text {th }}$ centuries.

\begin{tabular}{|c|c|c|}
\hline Author & Latin name & English translation \\
\hline $\begin{array}{c}\text { Aldrovandi 1606: } \\
\text { 358-359 }\end{array}$ & Turbo levis item in stagnis degens & Turbo with smooth shell, living in stagnant waters \\
\hline Lister 1678: 137 & $\begin{array}{c}\text { Buccinum longum } 6 \text { spirarum, omnium \& maximum } \\
\begin{array}{c}\text { \& productius, subflavum, pellucidum, in tenue acu- } \\
\text { men ex amplissima basi mucronatum }\end{array}\end{array}$ & $\begin{array}{c}\text { Buccinum with long [shell] having six whorls, whole, large, } \\
\text { oblong, yellowish coloured, transparent, [apex] sharp and } \\
\text { narrow, [shell] basis very ample }\end{array}$ \\
\hline Bonanni 1709: 453 & $\begin{array}{l}\text { Longior antecedenti Turbo, levissimus, colore atro } \\
\text { cum nitore }\end{array}$ & $\begin{array}{c}\text { Turbo longer than the antecedent [species], smoothest, } \\
\text { [shell] dark colored, glossy }\end{array}$ \\
\hline Gualtieri 1742: [34] & $\begin{array}{c}\text { Buccinum fluviatile, testa tenuissima, \& fragillissima, } \\
\text { prima spira notabiliter ventricosa, \& elongata, in } \\
\text { mucronem aculeatum statim definens, subflavum, } \\
\text { pellucidum }\end{array}$ & $\begin{array}{c}\text { Buccinum riverine, shell very narrow and fragile, the first } \\
\text { whorl notably inflated and oblong, [shell] ends with sharp } \\
\text { apex, yellowish, transparent }\end{array}$ \\
\hline $\begin{array}{l}\text { Linnaeus 1746: } \\
374\end{array}$ & $\begin{array}{c}\text { Cochlea testa producta cuminata opaca, anfractibus } \\
\text { senis subangularis, apertura ovata }\end{array}$ & $\begin{array}{c}\text { Cochlea with elongated dark coloured shell having six suban- } \\
\text { gulate whorls and ovale aperture }\end{array}$ \\
\hline Seba 1758: 119 & $\begin{array}{c}\text { Cochlea fluviatilis, indigena, ex oblongo acuminata, } \\
\text { lineolis veluti taeniata }\end{array}$ & $\begin{array}{c}\text { Cochlea riverine, native [= European], with oblong and point- } \\
\text { ed shell, covered by thin lines }\end{array}$ \\
\hline Klein 1755: 54-55 & $\begin{array}{c}\text { Auricula stagnorum - subflava, pellucida, in tenue } \\
\text { acumen ex amplissima basi mucronata }\end{array}$ & $\begin{array}{l}\text { Auricula stagnorum - [shell] yellowish and transparent, } \\
\text { with pointed apex and very wide [shell] basis }\end{array}$ \\
\hline $\begin{array}{l}\text { Schlotterbeccius } \\
\text { 1762: } 283\end{array}$ & $\begin{array}{c}\text { Turbo fluviatilis major, corpore oblongo ampullaceo } \\
\text { definente in mucronem acutissimum \& limacem } \\
\text { continente fuscum }\end{array}$ & $\begin{array}{c}\text { Turbo riverine, large, body [= shell] oblong, inflated [in its } \\
\text { base] and ending by a sharpest apex; it contains soft body of } \\
\text { contunuosly dark coloration. }\end{array}$ \\
\hline Geoffroy 1767: 72 & Buccinum testa oblonga, fusca, anfractibus senis & $\begin{array}{l}\text { Buccinum with oblong shell of brownish black colour, having } \\
\text { six whorls }\end{array}$ \\
\hline $\begin{array}{l}\text { Favart d'Herbigny } \\
\text { 1775: } 139\end{array}$ & $\begin{array}{l}\text { Buccinum fluviatile, testa tenui et fragili, forma ob- } \\
\text { longa, ventricosa; sex spiris exertis parum convexis } \\
\text { in apice acuto definentibus compositum; colore cor- } \\
\text { neo, pellucido, apertura spatiosa, elongata, integra, } \\
\text { et labio expanso distinctum }\end{array}$ & $\begin{array}{l}\text { Buccinum riverine, its shell is narrow and fragile, oblong and } \\
\text { inflated; it consists of six slightly convex whorls ending with } \\
\text { a sharp apex; [shell] horny-coloured, transparent, aperture } \\
\text { ample, elongated, whole, differs by a wide lip }\end{array}$ \\
\hline $\begin{array}{l}\text { Chemnitz 1786: } \\
166\end{array}$ & $\begin{array}{c}\text { Helix }<\ldots>\text { testa albida, pellucida, superne turrita, } \\
\text { inferne ventricosa, apertura effusa seu ampliata, } \\
\text { columella sinuosa }\end{array}$ & $\begin{array}{l}\text { Helix }<\ldots>\text { [with] whitish pellucid shell, in its upper part it is } \\
\text { turreted; the lower part is inflated. Aperture ample or wide; } \\
\text { columella folded }\end{array}$ \\
\hline
\end{tabular}

sential characters needed to be revealed in order to express what the species is and how to distinguish it from its congeners. The more species there were in a genus, the longer the species' names had to be produced (Pavlinov 2013). A polynomial is a name bearing the diagnosis of the taxon itself and it is very far from the Linnaean binomen, which is merely a useful verbal label serving to be remembered quickly (Vinarski 2013). The Linnaean name of the species under discussion, Helix stagnalis, contains no information about the essence of this species since it highlights the ecological preference of the great pond snail to live in stagnant waters. Certainly, this characteristic may be applied to numerous other species of European aquatic snails.

The essence of a taxon was an Aristotelian category not seen directly by the eyes, but being a mental construction based on the subjective weighting of animal characters aimed to distinguish between essential and secondary (accidental) ones. A modern scientist would say the essential diagnosis is a hypothesis since different authors may come to different views on which characters are essential and which are accidental. Therefore there was no commonly accepted scientific name for the great pond snail before Linnaeus' (1758) work. I collected a series of different polynomial names proposed from 1606 to 1786 for the designation of this species (it is by no means complete), and it is easy to see that no two authors had the same definition of its "essence" (Table 1).

The next step in the study of the great pond snail was undertaken almost 70 years later, in England. Martin List- er (1639-1712) was an English physician and naturalist, and vice-president of the Royal Society. He contributed extensively to many branches of science, including arachnology (Roos 2011) and chemistry (Roos 2008). Lister was a devoted conchologist and became the author of the first European treatises on mollusks (Historiae Conchyliorum, 1685; Conchyliorum Bivalvium, 1696). O.F. Müller (1774: xiii) called him "Conchyliologorum princeps" (head of conchologists) proposing a clear analogy with Linnaeus' informal title "Princeps botanicorum". Lister made numerous observations of mollusks' morphology (both external and internal), feeding, ecology, and distribution. His conchological works also included a description of the fossil species of shells.

In Lister's Historiae animalium Angliae tres tractatus (Lister 1678), one may find a detailed account of L. stagnalis that follows much higher standards of zoological descriptions compared with Aldrovandi's. This text contains not only the polynomial name (= short diagnosis) for this species but also a relatively long two-page sketch of the great pond snail's bionomics. Lister provides a lengthy general description of the animal's external morphology (including the pattern of mantle pigmentation), the shape of its excrements, the mode of copulation, the structure of egg-masses alongside a list of aquatic plants being its food. Some localities of L. stagnalis in England were also mentioned. Lister's species' account was almost 100 years ahead of its time. This high standard of publication of malacological data was not established un- 


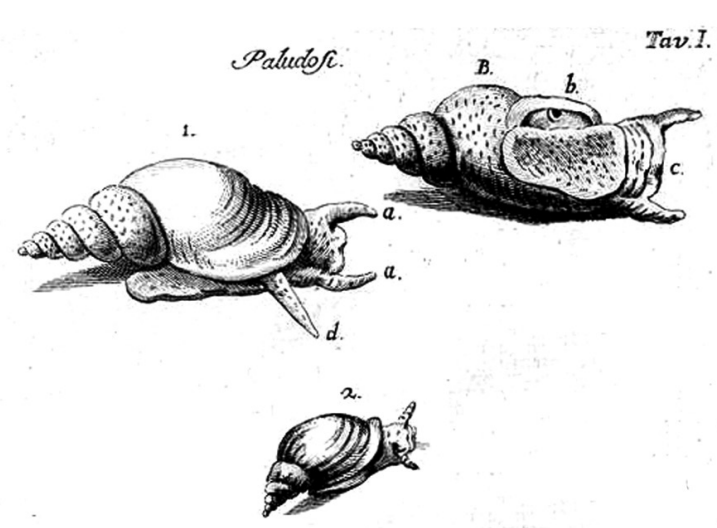

Figure 3. Illustrations of living L. stagnalis by Ginanni (1757).

til the end of the $18^{\text {th }} /$ early $19^{\text {th }}$ centuries when comparable works of European naturalists appeared (Müller 1774; Draparnaud 1805).

The picture of the great pond snail shell given by Lister (1678) is more informative than that by Aldrovandi though it is still rather crude and depicts a sinistral shell (see Fig. 2B).

Later on, Lister (1695) published a very detailed account of the L. stagnalis internal structure accompanied by engravings. Trained as a medicus, Lister was a brilliant anatomist aiming to dissect mollusks belonging to different taxa, both terrestrial and aquatic. He even estimated his own purely medical works as being of lower importance than his studies of molluscan anatomy (Heppel 1995). Another perfect anatomist of the age, Jan Swammerdam (1637-1680), was also interested in freshwater mollusks, and his study of the L. stagnalis anatomy was published posthumously in the author's prominent book Bybel der natuure (Swammerdam 1738). However, in both cases the advance of anatomical research did not enhance the progress in taxonomy. Systematists of the $17^{\text {th }}$ and $18^{\text {th }}$ centuries typically did not use anatomical information in their works, and the classification of mollusks long remained purely conchological (Vinarski 2014b). The use of anatomical data in lymnaeid taxonomy did not start until the first half of the $20^{\text {th }}$ century (Baker 1911; Roszkowski 1914).

Most subsequent authors, whose works were published between the works of Lister and Linnaeus, were mere collectors of deposited shells of L. stagnalis and other freshwater species in their private museums and shell "cabinets". This form of hobby was extremely popular among European noblemen and the educated part of the middle class in the $17^{\text {th }}$ and $18^{\text {th }}$ centuries (Dance 1966). Some of these proud collectors published voluminous books targeted to present their treasures to a wide audience. Sometimes such books contained high quality hand-colored illustrations and therefore were extremely expensive (Dance 1966). Typically, their authors did not give lengthy accounts on species' morphology and bionomics and restricted themselves to the simplest scheme of exposition: a short diagnosis (i.e. polynomial name) of a species plus a picture of its shell. This scheme was used, among others, by Bonanni (1709), Gualtieri (1742), and Seba (1758). The quality and accuracy of shell images greatly increased through the $17^{\text {th }}$ and $18^{\text {th }}$ centuries, with the most accurate illustrations appearing in the 1770s (Fig. 2). Sometimes, rather realistic portraits of living snails appeared; for example, those of crawling pond snails in Ginanni's (1757) posthumous book. Ginanni's image is morphologically correct and depicts some important details such as the shape of tentacles and the respiratory opening of the animal (Fig. 3 compare with Fig. 1).

Klein (1753) was the first author to separate lymnaeid snails into a taxon of their own - the genus Auricula with three species included. Before Linnaeus' seminal work (Linnaeus 1758), Klein already used binomial nomenclature and introduced the first two-part name for the great pond snail-Auricula stagnorum. This name has a formal priority before the Linnaeus' Helix stagnalis but, being published before 1758, it was not available for taxonomical and nomenclatorial purposes.

\section{Post-Linnaeus taxonomy: discovery of an intraspecific variation}

Carolus Linnaeus, the Swede, was a great botanist and reformist of biological taxonomy, but his malacological (or, more correctly, conchological) works received rather low esteem among next authors. For example, Maton and Rackett (1804: 175) stated that "there has been a very general belief that less attention was devoted by Linnaeus to the history and arrangement of the Testacea than to any other order of the animal kingdom, and that he even thought their external coverings, or shells, scarcely worthy of becoming subjects of scientific distribution". Donovan (1807) expressed his disgust with the Linnaean conchological works in stronger phrases: "an opinion is pretty generally prevalent that less attention was devoted by Linnaeus to the history and arrangement of the testacea, than any other order of nature; and that he even thought them unworthy of becoming objects of scientific arrangement. These points have been contested. The truth however dill appears to be, that Linnaeus had not really bestowed much critical attention on this subject $<\ldots>$ When therefore the completion of the Systema required that some attention should be paid to testaceology, he was unprepared, and referring to the authorities of others, comprised this department in the smallest compass possible, more with the view of filling up a chasm, which the omission of a tribe so generally admired would occasion, than from any idea of elucidating the subject $<\ldots>$ It is time we should lay aside the trammels of servile adherence, and speak decidedly: - those early attempts of this celebrated writer, we do not scruple to say, if examined with candour, will be found only a slight and ill conceived compendium of what has been handed down to us by antecedent writers" (italics added by me).

The examination of several descriptions of L. stagnalis found in Linnaeus works (Linnaeus 1746, 1758, 1761, 
1767) allows one to agree with the abovequoted words. Linnaeus did not move forward as compared with his predecessors (except for Lister). In 1746 he still used polynomials as the means of species designation (see Table 1). Since 1758, his species descriptions became two-part: the short binomial name proposed for the sake of utility accompanied by more detailed diagnosis being, in essence, nothing other than a traditional polynomial name (Pavlinov 2013). Thus, the great pond snail was christened in 1758 as Helix stagnalis and provided with a short diagnosis " $H[$ elix $]$ testa imperforata ovato-subulata subangulata, apertura ovata" (Linnaeus 1758: 774). Subsequent editions of "Systema Naturae" brought no new information on the great pond snail (Linnaeus 1767; Gmelin 1791).

Linnaeus and his immediate follower Johann Friedrich Gmelin (1791) did not recognize any variation within the species Helix stagnalis. The diagnosis of this taxon was presented as a list of essential conchological traits as if all snails were completely identical in their shell appearance. Though Linnaeus himself paid much attention to the problem of intraspecific variation in his theoretical works (i.e. in Philosophy of Botany; Linnaeus 1751), he was interested mainly in variations in plants. In the zoological part of Systema Naturae only a few animal species were mentioned as having varieties in their structure (notably, Homo sapiens Linnaeus, 1758 was among these species).

As a rule, animal taxonomists of the second half of the seventeenth century were still not aware of the existence of intraspecific variation (Vinarski 2013), though the most gifted observers among them knew well that there is some degree of phenotypical heterogeneity within common and widespread species. Possibly, the Danish naturalist Otto Frederick Müller (1730-1784) was the first student of non-marine mollusks to make an attempt to reflect this heterogeneity in a taxonomic work. Müller's opus magnum Vermium terrestrium et fluviatilium (Müller, 1774) became the most influential monograph on terrestrial and freshwater mollusks published between Systema Naturae and the dawn of the nineteenth century. Müller was a really great naturalist with a special interest in aquatic creatures, including infusorians, rotifers, crustaceans, and mollusks. He was the first naturalist to use a dredge for sampling benthic animals of inland waterbodies (Anderson and Rice 2006). Müller's species descriptions were rather lengthy and informative though Vermium terrestrium et fluviatilium did not contain illustrations of any described objects. The Dane established a new standard of arrangement of intraspecific variation in malacological treatises. His approach presupposed the enumeration of as many intraspecific varieties as was possible, each given a polynomial name serving as the diagnosis. The Greek alphabet letters were used for formal designation of these varieties. In some species of mollusks, especially of terrestrial ones, a number of such varieties could be rather high. For instance, Müller (1774) could distinguish 27 varieties of the common European garden snail, Cepaea nemoralis (L., 1758), designated by combinations of Greek letters, $\alpha$ to $\delta \delta$. In aquatic snails, Müller (1774) identified far fewer varieties, and no intraspecific group was described within L. stagnalis at all. Nevertheless, this approach was accepted by subsequent students of freshwater mollusks (Draparnaud 1805; Pfeiffer 1821; Nilsson 1822).

At the end of the $19^{\text {th }}$ century, the practice of recognition of varieties in L. stagnalis reached its summit in the works of S. Clessin $(1884,1887)$ and C. A. Westerlund $(1885,1897)$. Westerlund was, perhaps, the most prolific maker of varieties. He was able to determine as many as 19 varieties of the great pond snail in the Scandinavian region alone (Westerlund 1897), though he did not give a key for their exact categorisation. The users of his taxonomic catalogues were provided with only German or Latin diagnoses of the varieties with no chance to know the characters to distinguish among them precisely. The readers of Clessin's books $(1884,1887)$ were in a slightly more favourable position since the author illustrated shells of most varieties. This simple scheme of „species and its varieties" was applied in several influential malacological works of the $20^{\text {th }}$ century; for instance, in those by Ehrmann (1933) and Zhadin (1952).

Having searched through the old malacological literature, I compiled a synonymy of $L$. stagnalis $\mathrm{s}$. lato that contains nearly 80 varieties of this species described between the 1820s and 1920s (Electronic Appendix 1) A closer examination of this „zoo“ reveals a plethora of causes serving as grounds for establishing new varieties. I had an opportunity to examine many of these varieties using samples of $L$. stagnalis identified by malacologists of the $19^{\text {th }}$ century (Fig. 4) and now kept in the Europe's scientific institutions. It gave me a possibility to outline a rough classification of the varieties depending on the basis of their recognition. At least seven large groups of varieties may be separated:

1. Those reflecting variation in shell size. Example: $L$. stagnalis var. major Moquin-Tandon, 1855. Sometimes, shells of knowingly juvenile individuals were described as a distinct variety ( $L$. stagnalis var. junior Nilsson, 1822).

2. Sinistral mutants: L. stagnalis var. sinistrorsa Jeffreys, 1862.

3. Variants of the shell surface colouration: L. stagnalis var. bicolor Hartmann, 1840; L. stagnalis var. roseolabiata Beck, 1837; L. stagnalis var. fasciata Merkel, 1908.

4. Varieties based on shell proportions: L. stagnalis var. ampliata Clessin, 1876; L. stagnalis var. producta Colbeau, 1859.

5. Varieties based on peculiarities of shell structure, including structure of aperture and umbilicus, whorls' shape: L. stagnalis var. umbilicata Hutton, 1905.

6. Varieties based on ecological preferences: L. stagnalis var. lacustris Studer, 1820; L. stagnalis var. alpicola Gredler, 1859

7. Geographical races: L. stagnalis var. bottnica Westerlund, 1884; L. stagnalis var. gallica Bourguignat, 1864.

8. Varieties based on conchological similarity with other lymnaeid taxa: L. stagnalis var. palustriformis Kobelt, 1870. 


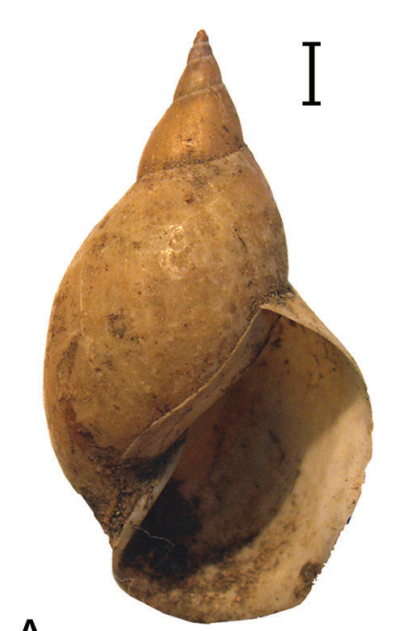

A
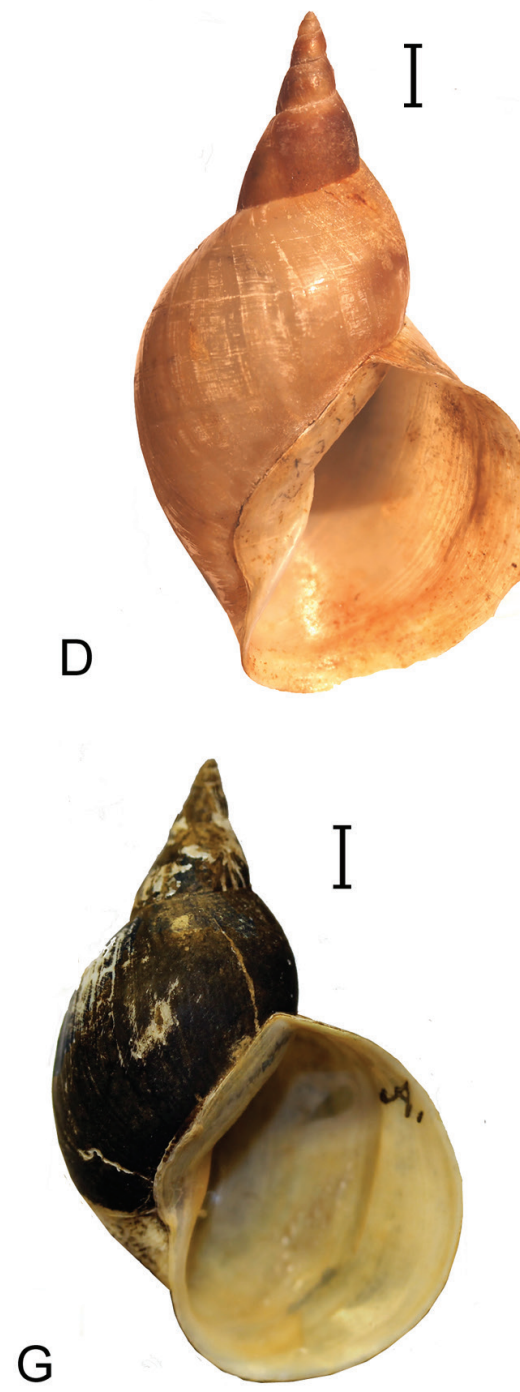
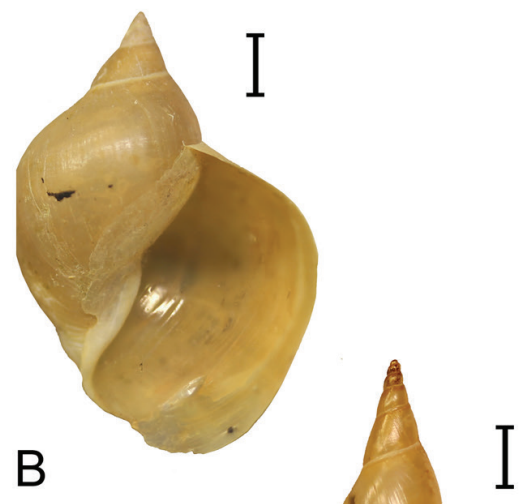

C

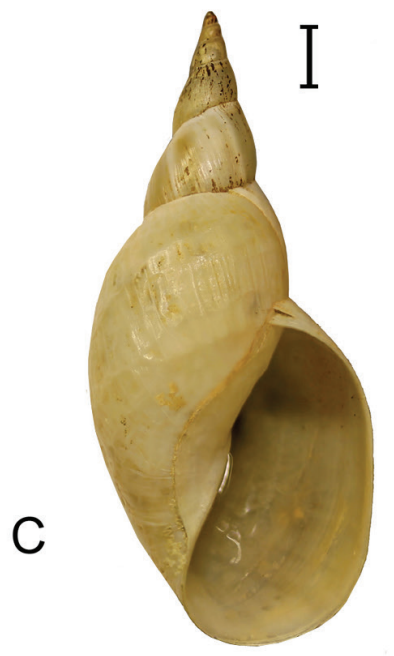

F
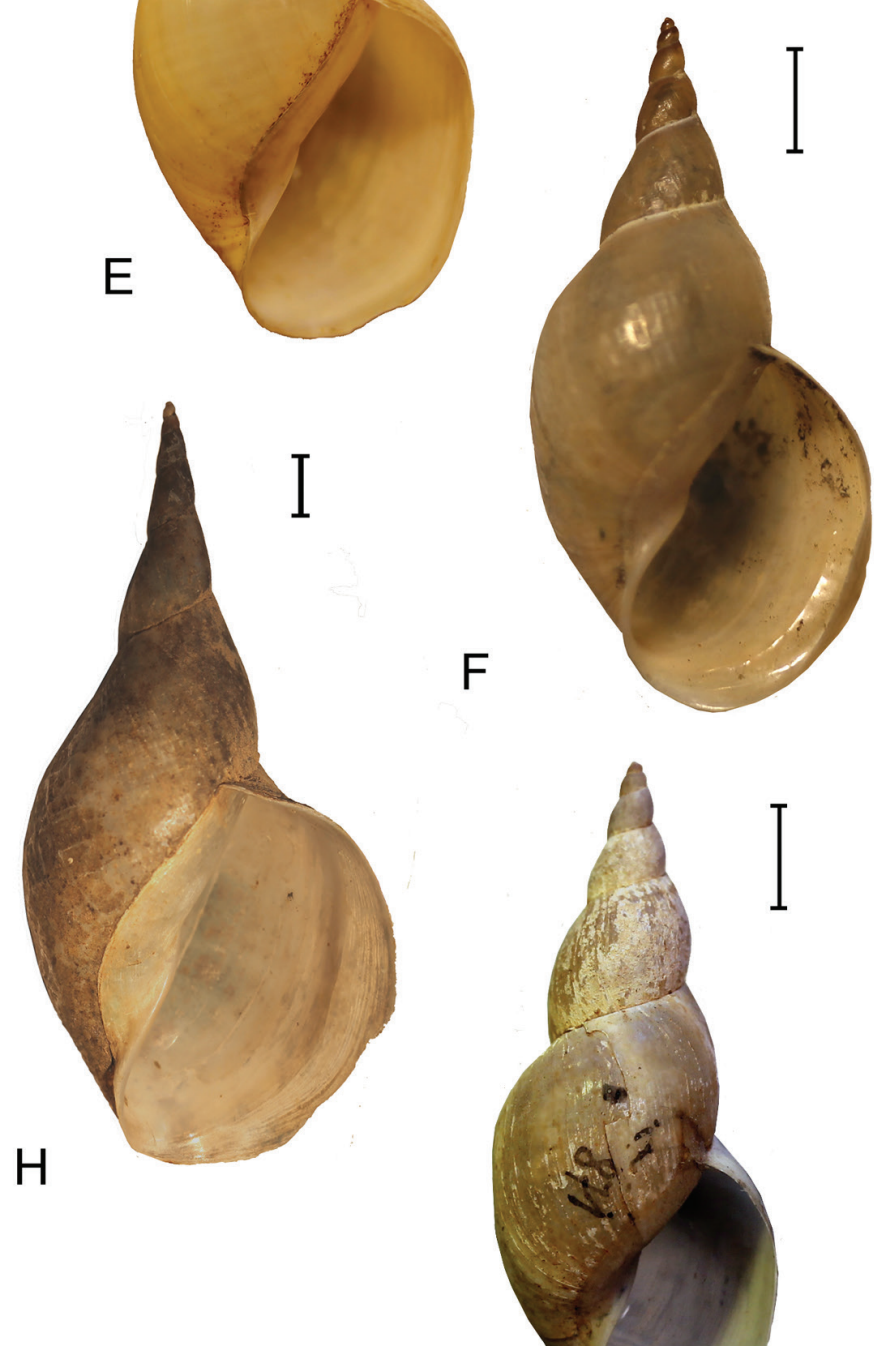
This short review shows how vague and indeterminate was this common practice of the discrimination of varieties. Zhadin $(1952 ; 166)$ rightly advised the readers / users of his key that ,we do not recommend to fit each collected shell to some variety; in most cases it is enough to give the shell measurements and only very divergent shells should be illustrated by drawings or photographs“.

Some authors attempted to reduce this vagueness by making demand that only those varieties that are found to have a hereditary basis are real. For instance, Chaster (1907: 28) proposed a new definition of variety in malacology: ,a variety is a group of individuals that differs from the typical or normal form in more or less distinct characters which are transmissible to the offspring".

Nevertheless, the most peculiar approach to the systematization of pond snails was realized by a group of French malacologists of the second half of the nineteenth century known under the name "Nouvelle École" (Dance 1970). The followers of it believed that a new species should be established if an individual is found to differ from all others by three characters or more (Davies 2004). Such a method led them to accept a huge number of nominal taxa of species' rank on the basis of very slight differences, usually in shell shape and proportions. Thus Locard (1893) was able to recognize no less than 22 "species" corresponding to L. stagnalis s. lato in the fauna of France alone (see Electronic Appendix 2). Most of these taxa were plain varieties raised to the rank of species. The unreliability of this approach was obvious, and no malacologist outside France could accept it.

A seemingly more productive approach to the L. stagnalis group taxonomy was proposed in Germany by Wilhelm Kobelt (1840-1916), a prominent zoologist who was also a strong critic of the "Nouvelle École" methods. Kobelt (1871) supposed that the shell variation in great pond snails has essentially ecological character, and their shell shape and proportions are moulded environmentally. Kobelt considered L. stagnalis as a Formenkreis ("circle of forms"), i.e. as a polymorphic species consisting of a series of ecological races that, in turn, embrace a plethora of varieties described prior to 1871 . He distinguished at least four ecological forms (races) denoted by vernacular German names:

1. "Normalform" (a typical morph, see Fig. 4A).

2. "Hungerform" (a starvation morph) - dwarf phenotype of L. stagnalis arising allegedly as a result of food shortage.

3. "Seeform" - a phenotype of large lakes.

4. "Kanalform" - a phenotype produced in canals.

Kobelt's idea helped to reduce the mammoth number of varieties to a few comprehensible entities with relatively clear content. Its influence may be traced in the works of David Geyer (1927) in Germany and Vladimir Zhadin $(1933,1952)$ in USSR, who used the Formenkreis concept to outline a circle of varieties within widespread species of freshwater snails, including L. stagnalis, Radix auricularia (L., 1758), Planorbarius corneus (L., 1758) and others. In this context, Hans Modell's (1922) attempt to build a taxonomic framework for freshwater unionid mussels (very variable like lymnaeids) on the basis of the recognition of intraspecific ecological morphs is of high interest as another realization of Kobelt's idea.

\section{Population thinking and its consequences: twentienth century systematics}

The advent of population genetics in the 1910-1920s brought to malacologists a new way of thinking capable of explaining the great pond snail variation. The futility of establishing an endless number of obscure varieties was demonstrated by Mozley (1937), who insisted that it is almost senseless to use standard shell measurements and their ratios for the exact determination of $L$. stagnalis varieties. The cause was that the overall conchological variation in a particular waterbody is sometimes so wide that "it may approach the range of variation which is to be found over the whole of the geographical range of the species" (Mozley 1937: 185). Instead, Mozley proposed to use the "local race" concept, according to which each more or less isolated habitat, pond or lake, has its own recognizable race of L. stagnalis. Mozley himself observed such a situation in Finland, where these races are common and, more importantly, "do not appear to be specially adapted to the local conditions under which they live" (Mozley 1937: 186). Thus the local races are not identical to ecological races according to Kobelt (1871). The main factor of their origin is the spatial separateness of waterbodies preventing the gene flow among populations.

This idea was a consequence of a quite novel form of biological thought known under the label "population thinking" (Mayr 1982). This population thinking shifted biologists from the study of single (or few) individuals to the examination of representative samples of animals by means of the rigorous statistical methods developed by biometrics. Most students agreed that character variation in natural populations is a norm rather than an annoying exception (Vinarski 2013), and the biometric studies revealed the continuous characters of shell variation not comparable with the concept of many distinct varieties within a species.

Further progress in biometric studies and conchometry based on measurements of large samples for drawing statistical inferences led to the complete renunciation of the local race concept in "freshwater" malacology. Eventually it became a trivial fact that any well isolated population of a given species should differ phenotypically from other populations of the same species. A total number of local races of $L$. stagnalis would be positively immense, so that makes the concept itself impracticable. Another cause of neglect of local races and similar intraspecific entities were anatomical studies focused mainly on the reproductive morphology of lymnaeids. Though the first information on L. stagnalis anatomy was obtained as ear- 
Table 2. Taxonomy of the Lymnaea stagnalis species complex according to Kruglov and Starobogatov (1993).

\begin{tabular}{|c|c|c|}
\hline Subgenus & Section & Species \\
\hline \multirow[t]{3}{*}{ Lymnaea } & Lymnaea s.str. & $\begin{array}{l}\text { 1. L. doriana (Bourguignat, 1862) } \\
\text { 2. L. fragilis (L., 1758) } \\
\text { - L. fragilis fragilis } \\
\text { - L.f. producta (Colbeau, 1859) } \\
\text { 3. L. stagnalis (L., 1758) } \\
\text { - L. stagnalis stagnalis } \\
\text { - L. s. turgida (Hartmann, 1840) }\end{array}$ \\
\hline & Kobeltilymnaea Kruglov \& Starobogatov, 1993 & 4. L. araratensis Kruglov \& Starobogatov, 1985 \\
\hline & Stagnaliana Servain, 1881 & $\begin{array}{l}\text { 5. L. media (Kobelt, 1877) } \\
\text { 6. L. bodamica (Miller, 1873) }\end{array}$ \\
\hline
\end{tabular}

ly as the $17^{\text {th }}$ century (M. Lister, J. Swammerdam), its taxonomic relevance was not acknowledged until the 1910s (Baker 1911; Roszkowski 1914). Pioneering work with broad taxonomic use of data on lymnaeid anatomy was published by Frank C. Baker (1911), a prominent American malacologists, who tried to construct a system of Lymnaeidae on the joint conchological-anatomical basis. Bengt Hubendick, the Swedish malacologist, put anatomy as the only cornerstone of his worldwide system of the family (Hubendick 1951). He failed to find any qualitative anatomical differences among conchologically distinct morphs and varieties of L. stagnalis. Hubendick (1951) identified all these intraspecific entities as mere conchological variants of the same biological species, having no real taxonomic significance. Anatomical features of lymnaeid snails were thought to be of much higher taxonomic value compared to the conchological ones. After Hubendick, most authors viewed L. stagnalis as a conchologically heterogenous but anatomically uniform species with no intraspecific taxa in its structure (Piechocki 1979; Jackiewicz 1998; Glöer 2002).

In the twenthienth century, the Synthetic Theory of Evolution (STE) absolutely dominated over biologists' minds. One of the most influential STE constituents was the so called 'biological species concept' (BSC) that is universally known and needs no detailed exposition here. I wish only to remind that BSC sees species as isolated gene pools able to keep their integrity due to complete or almost complete absence of gene flow among them (Mayr 1982; Wilkins 2009). Hubendick (1951) acknowledged the theoretical significance of BSC but refuted its practical application to the systematization of lymnaeids. He stated that a realization of BSC guidelines "offers considerable difficulties. A strictly practical application involves the conducting of crossing experiments between individuals from different populations. To carry out such a noteworthy degree with the Lymnaeids $<\ldots>$ is impossible in practice" (Hubendick 1951: 35).

The first attempt to apply BSC in lymnaeid systematics was undertaken in the USSR in the 1970s and 1980s by N.D. Kruglov and Ya.I. Starobogatov. They adopted two main methods of systematization: artificial crossing experiments (Kruglov 1975; Kruglov and Starobogatov 1985) and the so called "comparatorial (or comparatory) method" invented by Logvinenko and Starobogatov (1971). The latter is based on an analysis of the subtle differences in shell growth patterns of closely allied species of snails and bivalves (Kruglov and Starobogatov 1985; Shikov and Zatravkin 1991; Graf 2007). Starobogatov and his numerous disciples applied this method in order to revise all families of freshwater mollusks of the former USSR. Though Graf (2007) considers the comparatorial method as a peculiar "species concept", his statement is not fully correct since Starobogatov himself was a follower of BSC and published several papers on its application to the systematics of freshwater mollusks (Starobogatov 1968, 1977).

As a consequence, Kruglov and Starobogatov (1985, 1993 ) proposed a new taxonomic structure of the L. stagnalis complex drastically dissimilar to the Hubendick (1951) system. The great pond snail was thought to represent at least six independent species distributed among three sections of the genus Lymnaea (Table 2). I have to note, however, that only two species out of the six (L. stagnalis s.str., L. fragilis L., 1758) were really involved in the artificial breeding experiments conducted by the authors. The species status of the remaining taxa was proposed for the reason of lack of morphological intermediates between them under condition of syntopy. According to Starobogatov $(1968,1977)$, the absence of such intermediate specimens could serve as an indirect proof of the reproductive isolation between studied taxa and might be taken into account by taxonomists even if this alleged isolation was not tested experimentally. In particular, differences in geometric patterns of shell coiling between two forms revealed by means of the comparatorial method was regarded by some Russian workers as a solid proof of their belonging to different species (Shikov and Zatravkin 1991).

The fate of Kruglov and Starobogatov's (1985) crossing experiments is remarkable. Though their results appeared in an international malacological journal and the language of the publication was English, not Russian, a serious discussion on the subject did not started. Only Meier-Brook (1993) briefly discussed these experiments in his article devoted to the species problem in "freshwater" malacology: "If the criteria for the assessment of the descendants are convincingly as described in their paper, we have to admit logically that Kruglov \& Starobogatov are right to consider distinct species in this case" ("Wenn die Kriterien für die Beurteilung der Nachkommenherkunft so überzeugend sind, wie in ihrer Publikation beschrieben, wird man konsequenterweise zugestehen müssen, daß Kruglov \& Starobogatov Recht haben, hier von 
getrennten Arten auszugehen"' Meier-Brook 1993: 136). Other malacologists were not so loyal and either avoided any discussion or restricted themselves to general phrases with no sympathy for the "Russian" system ("opinions of Russian malacologists on the lymnaeid taxonomy $<\ldots>$ raised great doubts and $\langle\ldots\rangle$ have not been taken into consideration"; Jackiewicz 1998: 3).

I think this question could not be resolved in principle before the modern "revolution" in taxonomy that was triggered by introduction of the molecular genetic techniques in the 1980 s.

\section{The great pond snail in the brave new world}

The 'brave new world' of animal taxonomy relies heavily on inferences based on molecular studies and the quasi-cladistic way of bringing up and testing phylogenetic hypotheses (Mooi and Gill 2010). Though molecules are not the panacea for all puzzles systematists seek to solve, genetic methods provide us with an independent set of characters giving an opportunity to test hypotheses based on classical morphological studies. This has brought new possibilities and launched a new cycle of taxonomic studies on biological species, including the most well-studied ones such as L. stagnalis.

Already the first attempts to examine the internal diversity of L. stagnalis by molecular methods (Remigio and Blair 1997; Remigio 2002) revealed that its populations from different countries (Italy, Germany) and continents (Europe, North America) are separated by rather great genetic distances comparable with those separating distinct species of Lymnaeidae or even slightly exceeding them. Remigio (2002: 691) suggested that these populations "probably deserve at least subspecies status". The number of studied specimens/populations of L. stagnalis and the geographical scope in these early works were, however, not enough for making sound conclusions.

In 2008, a group of Ukrainian malacologists (Mezhzherin et al. 2008) submitted the two alleged species of the Kruglov and Starobogatov (1985) system, L. stagnalis s.str. and L. fragilis, to allozyme electrophoresis. They demonstrated that there are no significant genetic differences between these two taxa and they should be synonymized. Their reproductive isolation has also been questioned by Mezhzherin et al. (2008). An interesting pattern of congruence between genetic diversity and geography in the great pond snail was found: in the Ukraine, populations of $L$. stagnalis s. 1. form two genetically distinct groups, "western" and "eastern", with the boundary between them lying somewhere in the central part of the country. Mezhzherin et al. (2008) proposed to treat the two groups as allospecies (sensu Amadon 1966) within the superspecies L. stagnalis s. 1.

Having used the DNA sequencing technique and four gene markers (two nuclear and two mitochondrial), Vinarski et al. (2012) obtained results similar to those of Mezhzherin et al. (2008). In their study, two large genetically distinct groups whose distribution is clearly correlated with geography (geogroups) were found to exist within Palearctic L. stagnalis s. 1. One of them is of mainly western distribution being found throughout Europe (except for the eastern parts of Ukraine and European Russia), and the second is widely distributed in Asia, from Transcaucasia eastwards to Mongolia, Tajikistan, and Lake Baikal. Most probably, these geogroups correspond to the two allospecies discovered by Mezhzherin et al. (2008) and therefore the use of the superspecies concept (Amadon 1966) is justified in this case. The phylogeographic pattern of the great pond snail, with separation of the species into two large divisions with eastern and western Palearctic distribution, resembles a number of similar examples found in different animal taxa, including freshwater amphipods (Vainio and Väinölä 2003), amphibians (Borkin et al. 2004), fish (Makhrov and Bolotov 2006) and mammals (Marmi et al. 2006). The usual explanation for such phylogeographic patterns is that of invoking Pleistocene glacial events, including the long isolation of groups of populations in refugia and the following recovery of the former range with the formation of zones of secondary intergradation.

However, a thorough analysis of morphological variation in L. stagnalis s. 1. shows that the internal structure of the species cannot be restricted to molecularly defined groups. Though numerous morphs and varieties of the great pond snail lack the genetic support, the reality of some morphologically distinct entities within it has been proved by statistical methods (Vinarski 2014a). Four or five conchologically defined "morphotypes" can be delineated within L. stagnalis in Palearctic, with two of them, L. stagnalis (f. typica) and L. fragilis sensu Kruglov and Starobogatov being the most widely distributed (Vinarski 2014a). From the phylogenetic point of view, however, these morphotypes do not constitute separate clades and may arise in both geogroups in parallel. Their spatial distribution is apparently not governed by ecological or physical geographical factors (Vinarski et al. 2012; Vinarski 2014a).

These results represent a clear example of drastic incongruence between molecular and morphological data. Though the validity of "minor" species of the great pond snails accepted by Kruglov and Starobogatov (1985, 1993) was not corroborated genetically, the question of a possible existence of "cryptic" species (or other taxonomically significant entities of lower rank) within L. stagnalis s. lato remains opened. In my opinion, both "dimensions" of the species, genetic and morphological, are worthy of study since provide us with additional evidence and as such may be used in an integrative taxonomic approach. The geogroups teach us something of the history of the species' range and alleged Plestocene refugia. The morphotypes reflect another, functional aspect of biodiversity additional to the taxonomic one that may be measured at the infraspecific level (Albert et al. 2012). It has been assumed that conchological differences between the morphotypes may be of some adaptive value (Vinarski 2014a).

Nevertheless, this brave new view on L. stagnalis will, possibly, change in the nearest future since new, more 
powerful methods of molecular study (next generation sequencing, transcriptomics) are coming. The application of these methods may bring essentially new results concerning the great pond snail - this long studied but still not completely understood species.

\section{Acknowledgements}

I would like to thank museum curators for their help during my work: Pavel Kijashko and Lidiya Yarochnovich (Sankt-Petersburg), Anita Eschner (Vienna), Tom Schiøtte (Copehnagen), Ted von Proschwitz (Gothenburg) and Anders Warén (Stockholm). I thank also Peter Glöer (Hetlingen) for translation from the Meier-Brook (1993) paper on my request. Peter Glöer, Katrin Schniebs (Dresden), Anna Hundsdoerfer (Dresden), and Ivan Nekhaev (Murmansk) are acknowledged for discussions on diverse aspects of taxonomy and phylogeography of Lymnaea stagnalis. Comments and suggestions from three reviewers of MS have resulted in its significant improvement. I thank Andrew Show (English Language Centre Ltd, Omsk) for checking the English text. My taxonomic work in the zoological museums of Russia and Western Europe is supported financially by the Russian Fund for Basic Research (project No.14-04-01236_a) and the Russian Ministry of Education and Science (project No. № 6.1957.2014/K).

\section{References}

Albert C, de Bello F, Boulangeat I, Pellet G, Lavoel S, Thuiller W (2012) On the importance of intraspecific variability for the quantification of functional diversity. Oikos 121: 116-126. doi: 10.1111/j.16000706.2011.19672.x

Aldrovandi U (1606) De reliquis animalibus exanguibus libri quatuor post mortem eius editi nempe de mollibvs, crvstaceis, testaceis et zoophytis. Bellagamba, Bologna, 593 pp.

Allmon WD (2007) The evolution of accuracy in natural history illustration: reversal of printed illustrations of snails and crabs in pre-Linnaean works suggests indifference to morphological details. Archives of Natural History 34: 174-191. doi:10.3366/ anh.2007.34.1.174

Amadon D (1966) The superspecies concept. Systematic Zoology 15: 246-249. doi: 10.2307/sysbio/15.3.245

Anderson TR, Rice T (2006) Deserts on the sea floor: Edward Forbes and his azoic hypothesis for a lifeless deep ocean. Endeavour 30: 131-137. doi: 10.1016/j.endeavour.2006.10.003

Arthur W (1982) Control of shell shape in Lymnaea stagnalis. Heredity 49 (2): 153-161. doi: 10.1038/hdy.1982.81

Atran S (1990) Cognitive foundations of natural history: towards an anthropology of science. Cambridge University Press, Cambridge, 360 pp.

Baker FC (1911) The Lymnaeidae of North and Middle America. Special publication of the Chicago Academy of Sciences 3: 1-539. http://www.biodiversitylibrary.org/bibliography/10622\#/summary

Bonanni P (1709) Musaeum Kircherianum, sive Musæum a P. Athanasio Kirchero in Collegio Romano Societatis Jesu jam pridem incœp- tum, nuper restitutum, auctum, descriptum, \& iconibus illustratum. Plachi, Roma, 522 pp.

Borkin LY, Litvinchuk SN, Rozanov YM, Skorinov DV (2004) On cryptic species (from the example of amphibians). Zoologicheskiy Zhurnal 83(8): 936-960. [In Russian]

Chapman G (1888) Homer's Batrachomyomachia, hymns and epigrams. Hesiod's Works and Days. Musaeus' Hero and Leander. Juvenal's Fifth Satire. J. R. Smith, London, 237 pp. https://archive.org/ details/HomersBatrachomyomachiaHymnsAndEpigrams

Chaster GW (1907) Species and variation. Journal of Conchology 12 (1): 20-32. http://www.biodiversitylibrary.org/item/99437\#page/9/ mode/1up

Chemnitz JH (1786) Neues systematisches Conchylien-Cabinet <..> enthaltend die ausführliche Beschreibung von den Land- und Flußschnecken, oder von solchen Conchylien, welche nicht im Meere, sondern auf der Erde und in süssen Wassern zu leben pflegen. Mit zwanzig nach der Natur gemalten und durch lebendige Farben erleuchteten Kupfertafeln. Raspe, Nürnberg, 151 pp.

Clessin S (1884) Deutsche-Exkursion-Mollusken-Fauna. Bauer \& Raspe, Nurnberg, 663 pp. doi: 10.5962/bhl.title.13049, http://www. biodiversitylibrary.org/bibliography/13049\#/summary

Clessin S (1887-1890) Die Mollusken-Fauna Österreich-Ungarns und der Schweiz. Bauer \& Raspe, Nürnberg, 858 pp. http://www.biodiversitylibrary.org/bibliography/60371\#/summary

Dance SP (1966) Shell collecting: An illustrated history. Faber \& Faber, London, $344 \mathrm{pp}$.

Dance SP (1970) "Le fanatisme du nobis": a study of J.-R. Bourguignat and the "Nouvelle École". Journal of Conchology 27: 65-86.

Donovan E (1807) Conchology - The Cyclopaedia; or, Universal Dictionary of arts, science, and literature. Longman, Hurst, Rees, Orme \& Brown, London. V. 9 (without pagination).

Draparnaud JPR (1805) Histoire naturelle des mollusques terrestres et fluviatiles de la France. Colas, Paris, 164 pp. http://www.biodiversitylibrary.org/bibliography/12856\#/summary

Ehrmann P (1933) Mollusca. In: Brohmer P, Ehrmann P, Ulmer G (Eds) Die Tierwelt Mitteleuropas. Quelle \& Meyer, Leipzig 2(1): 1-264.

Favart d'Herbigny CE (1775) Dictionnaire d'histoire naturelle, qui concerne les testacées ou les coquillages de mer, de terre \& d'eaudouce: avec la nomenclature, la zoomorphose, \& les différens systêmes des plusieurs célébres naturalistes anciens \& modernes: ouvrage qui renferme la description détaillée des figures des coquilles. Tome premier. Bleuet, Paris, 424 pp.

Geyer D (1927) Unsere Land- und Süsswasser-Mollusken. Lutz, Stuttgart, 224 pp.

Ginanni G (1757) Opere postume del conte Giuseppe Ginanni ravennati. Tomo secondo, nel quae si contegnano Testacei marittimi, paludosi e terrestri dell' Adriatico e del territorio di Ravenna, da lui osservati e descritti. G. Zerletti, Venezia, 72 pp.

Glöer P (2002) Die Sußwassergastropoden Nord- und Mitteleuropas: Bestimmungschlussel, Lebenweise, Verbreitung. Hackenheim, Conchbooks, 327 pp.

Gmelin JF (1791) Caroli a Linné Systema Naturae per regna tria naturae, secundum classes, ordines, genera, species, cum characteribus, differentiis, synonymis, locis. Editio decima tertia, aucta, reformata. G.E. Beer, Leipzig 1(6): 3021-3910. http://www.biodiversitylibrary.org/item/83098\#page/5/mode/1up

Graf DL (2007) Palearctic freshwater mussel (Mollusca: Bivalvia: Unionoida) diversity and the Comparatory Method as a species 
concept. Proceedings of the Natural Sciences of Philadelphia 156: 71-88. doi: 10.1635/0097-3157(2007)156[71:PFMMBU]2.0.CO;2

Gualtieri N (1742) Index testarum conchyliorum qvae adservantvr in mvseo Nicolai Gvaltieri (...) et methodice distribvta exhibentvr. C. Albizzino, Florenze, $110 \mathrm{pp}$.

Heppel D (1995) The long dawn of malacology: a brief history of malacology from prehistory to the year 1800. Archives of Natural History 22(3): 301-319. doi: 10.3366/anh.1995.22.3.301

Hubendick B (1951) Recent Lymnaeidae. Their variation, morphology, taxonomy, nomenclature and distribution. Kungliga Svenska Vetenskapsakademiens Handlingar. Fjärde Serien 3(1): 1-223.

Jackiewicz M (1998) European species of the family Lymnaeidae (Gastropoda, Pulmonata, Basommatophora). Genus 9(1): 1-93.

Jeffreys JG (1862) British Conchology. V. 1. J. van Voorst, London, 341 pp. http://www.biodiversitylibrary.org/item/55187\#page/9/mode/1up

Klein JT (1753) Tentamen methodi ostracologicæ sive dispositio naturalis cochlidum et concharum in suas classes, genera et species, iconibus singulorum generum aeri incisis illustrata etc. Wishoff, Leiden, 177 pp. http://www.biodiversitylibrary.org/ bibliography/14376\#/summary

Kobelt W (1871) Zur Kenntniss der europäischen Limnäen. II. L. stagnalis Linné. Malakozoologischer Blätter 18: 108-119.

Kruglov ND (1975) An analysis of modern methods of molluscan systematics and limits of their use (by the example of lymnaeid snails). Problems of systematics and ecology of animals of the Smolensk Region and adjacent regions. Smolensk, 12-28. [In Russian]

Kruglov ND, Starobogatov YI (1985) Methods of experimental hybridization and some results of its applications in the taxonomy of Lymnaeidae. Malacological Review 18: 21-35.

Kruglov ND, Starobogatov YI (1993) Annotated and illustrated catalogue of species of the family Lymnaeidae (Gastropoda Pulmonata Lymnaeiformes) of Palaearctic and adjacent river drainage areas. Part I. Ruthenica 3(1): 65-92.

Linnaeus C (1746) Fauna Svecica, sistens Animalia Svecicae Regni: Quadrupedia, Aves, Amphibia, Pisces, Insecta, Vermes, distributa per Classes \& Ordines, Genera \& Species. Cum differentiis Specierum synonymis Autorum, nominibus Incolarum, locis Habitationum, descriptionibus Insectorum. Laurentius Salvius, Stockholm, 411 pp. http://www.biodiversitylibrary.org/bibliography/63899\#/summary

Linnaeus C (1751) Philosophia botanica: in qua explicantur fundamenta botanica cum definitionibus partium, exemplis terminorum, observationibus rariorum, adjectis figuris aeneis. G. Kiesewetter, Stockholm, 362 pp. http://www.biodiversitylibrary.org/bibliography/72943\#/summary

Linnaeus C (1758) Systema naturæ per regna tria naturæ, secundum classes, ordines, genera, species, cum characteribus, differentiis, synonymis, locis. Editio decima, reformata. Laurentius Salvius, Stockholm, 824 pp. http://www.biodiversitylibrary.org/bibliography/542\#/summary

Linnaeus C (1767) Caroli a Linné ... systema naturae per regne tria naturae, secundum classes, ordines, genera, species, cum characteribus, differentiis, synonymis, locis... Editio duodecima, reformata. Laurentius Salvius, Stockholm 1(2): 533-1327 http://www. biodiversitylibrary.org/bibliography/68927\#/summary

Lister M (1678) Historiae animalium Angliae tres tractatus. Unus de Araneis. Alter de Cochleis tum terrestribus tum fluviatilibus. Tertius de Cochleis marinis. Quibus adjectus est quartus de Lapidibus ejusdem insulae ad cochlearum quandam imaginem figuratis. J. Martyn,
London, 250 pp. doi: 10.5962/bhl.title.65746, http://www.biodiversitylibrary.org/bibliography/65746\#/summary

Lister M (1695) Exercitatio anatomica altera, in qua maximè agitur de buccinis fluviatilibus \& marinis etc. S. Smith \& B. Walford, London, $395 \mathrm{pp}$.

Locard A (1893) Coquilles des eaux douces et saumâtres de France. Desctiption des familles, genres et espéces. Alexandre Rey, Lyon, 327 pp. http://www.biodiversitylibrary.org/bibliography/12982\#/summary

Logvinenko BM, Starobogatov YI (1971) Curvature of frontal section of the valve as taxonomical character in bivalve mollusks. Nauchnye Doklady Vysshey Shkoly, Biologicheskie Nauki 5: 7-10. [In Russian]

Makhrov AA, Bolotov IN (2006) Dispersal routes and species identification of freshwater animals in Northern Europe: A review of molecular evidence. Russian Journal of Genetics 42(10): 1101-1115. doi:10.1134/S1022795406100036

Marmi J, López-Giráldez F, Macdonald DW, Calafell F, Zholnerovskaya E, Domingo-Roura X (2006) Mitochondrial DNA reveals a strong phylogeographic structure in the badger across Eurasia. Molecular Ecology 15(4): 1007-1020. doi: 10.1111/j.1365294X.2006.02747.x

Martens E (1860) Die classischen Conchylien-Namen Jahreshefte des Vereins für vaterländische Naturkunde in Württemberg 16: 175-264. http://www.biodiversitylibrary.org/item/33441\#page/7/mode/1up

Mayr E (1982) The growth of biological thought. The Belknap Press of Harvard University Press, Cambridge (MA), 978 pp.

Meier-Brook C (1993) Artaufassungen in Bereich der limnischen Mollusken und ihr Wahd im 20. Jahrhundert. Archiv für Molluskenkunde 122: 133-147.

Mezhzherin SV, Garbar AV, Korshunova ED, Zhalay EI (2008) The analysis of morphological and genetic variation of the snail, Lymnaea stagnalis s. 1. (Gastropoda, Lymnaeidae), in Ukraine. Vestnik Zoologii 42(4): 339-345. [In Russian]

Modell H (1922) Beiträge zur Najadenforschung. I. Zur Systematik der mitteleuropäischen Najaden. Archiv für Naturgeschichte. Abteilung A 88: 156-171. http://www.biodiversitylibrary.org/ item/47606\#page/7/mode/1up

Mooi RD, Gill AC (2010) Phylogenies without synapomorphies, a crisis in fish systematics: it's time to show some character. Zootaxa 2450 : 26-40.

Mozley A (1937) A biological study of the Sub-Arctic Mollusca. Proceedings of the American Philosophical Society 78(1): 147-189. http://www.jstor.org/stable/984662

Müller OF (1774) Vermium terrestrium et fluviatilium seu animalium infusorium, helminthicorum et testaceorum non marinorum succincta historia. Heineck et Faber, Havniae et Lipsiae 2: 1-214. http:// www.biodiversitylibrary.org/bibliography/46299\#/summary

Nilsson S (1822) Historia molluscorum Sveciae terrestrium et fluviatilium breviter delineata. J.H. Schuboth, Lund, 124 pp. http://www. biodiversitylibrary.org/bibliography/16344\#/summary

Pavlinov YI (2013) Taxonomic nomenclature. Book I. From Adam to Linnaeus. Zoologicheskie Issledovania 12: 1-151. [In Russian] http://ashipunov.info/shipunov/school/books/pavlinov2013_taksonom_nomenkl_1.pdf

Pavlinov YI, Lyubarskiy GY (2011) Biological systematics: a history of the ideas. KMK Scientific Press, Moscow, 667 pp. [In Russian] http://ashipunov.info/shipunov/school/books/pavlinov_ljubarskij2011_istorija_sistematiki.djvu 
Pfeiffer C (1821) Naturgeschichte deutscher Land- und SüßwasserMollusken. Erste Abhteilung. Author's edition, Weimar, 135 pp.

Piechocki A (1979) Mięczaki (Mollusca). Ślimaki (Gastropoda). Fauna Słodkowodna Polski. Państwowe wydawnictwo naukowe, WarszawaPoznań 7: 1-188.

Remigio EA (2002) Molecular phylogenetic relationships in the aquatic snail genus Lymnaea, the intermediate host of the causative agent of fascioliasis: insight from broader taxon sampling. Parasitology Research 88: 687-696. doi: 10.1007/s00436-002-0658-8

Remigio EA, Blair D (1997) Molecular systematics of the freshwater snail family Lymnaeidae (Pulmonata: Basommatophora) utilising mitochondrial ribosomal DNA sequences. Journal of Molluscan Studies 63(2): 173-185. doi: 10.1093/mollus/63.2.173

Roos AM (2008) All that glitters: fool's gold in the early-modern era. Endeavour 32(4): 147-151. doi: 10.1016/j.endeavour.2008.10.001

Roos AM (2011) Web of Nature: Martin Lister (1639-1712), the first arachnologist. Brill Academic Publishers, Leiden, 478 pp. doi: 10.1163/ej.9789004207035.i-478

Roszkowski W (1914) Note sur l'appareil génital de Limnaea auricularia L. et de Limnaea ovata Drap. Zoologischer Anzeiger 44(4): 175-179. http://www.biodiversitylibrary.org/item/95255\#page/7/ mode/1up

Schmidtler JF (2010) The taxonomic history of the Linnean genus Lacerta (Squamata: Sauria: Lacertidae) in the mirror of book-illustration. Bonn Zoological Bulletin 57(2): 307-328. http://www. biodiversitylibrary.org/part/120210\#/summary

Schlotterbeccius PJ (1762) Observatio physica de Cochleis quibusdam, nec non de Turbinibus nonnullis, ut \& de Cochlea quadam petrefacta. Acta Helvetica, physico-mathematico-anatomico-botanico-medica, figuris aeneis illustrata, \& in usus publicos exarata 5-6: 275-288.

Schröter JS (1779) Die Geschichte der Flußconchylien mit vorzüglicher Rücksicht auf diejenigen welche in den thüringischen Wassern leben. Gebauer, Halle, 434 pp. doi: 10.5962/bhl.title.10484

Seba A (1758) Locupletissimi rerum naturalium thesauri accurata descriptio, et iconibus artificiosissimis expressio, per universam physices historium. Tomus III. J. Wetsten, W. Smith \& JanssonWaesbergios, Amsterdam, 212 pp. http://www.biodiversitylibrary. org/bibliography/75744\#/summary

Shikov EV, Zatravkin MN (1991) The comparative method of taxonomic studies of Bivalvia used by Soviet malacologists. Malakologische Abhandlungen Staatliche Museum für Tierkunde Dresden 15: 149-159.

Starobogatov YI (1968) Practical demands of systematics and problem of species criteria. Zoologicheskiy Zhurnal 47(6): 875-886. [In Russian]

Starobogatov YI (1977) On the relations between biological and typological species concepts. Zhurnal Obshchey Biologii 38(2): 157166. [In Russian]

Stevens PF (1994) The development of biological systematics: Antoine-Laurent de Jussieu, Nature, and the Natural System. Columbia University Press, New York, 616 pp.
Swammerdam J (1738) Bybel der natuure of historie der insecten, tot zeekere zoorten gebracht: door voorbeelden, ontleedkundige onderzoekingen van veelerhande kleine gediertens, als ook door kunstige kopere plaaten opgeheldert. Verrykt met ontelbaare waarnemingen van nooit ontdekte zeldzaamheden in de natuur. Alles in de hollandse, des auteurs moedertaale, beschreven. Hier by komt een voorreeden, waar in het leven van den auteur beschreven is door Herman Boerhaave. De Latynsche overzetting heeft bezorgt Hieronimus David Gaubius. II. deelen. I. Severinus, B. van der Aa \& P. van der Aa, Leiden 2: 551-990.

Vainio JK, Väinölä R (2003) Refugial races and postglacial colonization history of the freshwater amphipod Gammarus lacustris in Northern Europe. Biological Journal of the Linnean Society 79: 523-542. doi: 10.1046/j.1095-8312.2003.00207.x

Vinarski MV (2007) An interesting case of predominantly sinistral population of Lymnaea stagnalis (L.) (Gastropoda: Pulmonata: Lymnaeidae). Malacologica Bohemoslovaca 6: 17-21. http://www. biolib.cz/en/reference/id1696/

Vinarski MV (2013) Problem of variability in classical and nonclassical systematics. Studies in the History of Biology 5(2): 7-27. [In Russian]

Vinarski MV (2014a) A comparative study of shell variation in two morphotypes of Lymnaea stagnalis (Mollusca: Gastropoda: Pulmonata). Zoological Studies 53(69). doi: 10.1186/s40555-014-0069-4, http://www.zoologicalstudies.com/content/53/1/69

Vinarski MV (2014b) The birth of malacology: when and how? Zoosystematics and Evolution 90: 1-5. doi: 10.3897/zse.90.7008

Vinarski MV, Schniebs K, Glöer P, Hundsdoerfer A (2012) Preliminary phylogeography of Lymnaea stagnalis: are there cryptic species of the great pond snail? XI International Congress on Medical and Applied Malacology: Abstracts book. Sociedade Brasileira de Malacologia, Rio de Janeiro, 66.

Westerlund CA (1885) Fauna der in der Paläarktischen Region (Europa, Kaukasien, Sibirien, Turan, Persien, Kurdistan, Armenien, Mesopotamien, Kleinasien, Syrien, Arabien, Egypten, Tripolis, Tunisien, Algerien und Marocco) lebenden Binnenconchylien. V. Fam. Succineidae, Auriculidae, Limnaeidae, Cyclostomidae und Hydrocenidae. H. Ohlsson, Lund, 135 pp. http://www.biodiversitylibrary.org/ item/41051\#page/7/mode/1up

Westerlund CA (1897) Synopsis Molluscorum Extramarinorum Scandinaviae. Acta Societatis pro Fauna et Flora Fennica 13: 1-237. http:// www.biodiversitylibrary.org/bibliography/11407\#/summary

Wilkins JS (2009) Species: a history of the idea. University of California Press, Berkeley etc., 302 pp.

Zhadin VI (1933) The freshwater molluscs of the USSR. Lensnabtehizdat, Leningrad, 232 pp. [In Russian] http://ashipunov.info/shipunov/ school/books/zhadin1933_presn_moll_sssr.djvu

Zhadin VI (1952) Fresh- and brakishwater mollusks of the USSR. Sovetskaya Nauka, Moscow, 346 pp. [In Russian] http://ashipunov. info/shipunov/school/books/zhadin1952_molljuski_presn_solonov_vod_sssr.djvu 